\title{
Actualización de la política estatal en materia de alcohol: el caso de Brasil
}

\section{An update of public policy on alcohol: the case of Brazil}

\author{
Ilana Pinsky; Ronaldo Laranjeira \\ UNIAD (Centro de Investigación sobre el Alcohol y otras Drogas) \\ UNIFESP (Universidad Federal de Sao Paulo - Brasil.

\section{RESUMEN}

Este artículo muestra la situación actual de la política estatal brasileña en materia de alcohol y los esfuerzos realizados por ésta. Los datos epidemiológicos ponen de manifiesto que el consumo de alcohol es cada vez más elevado, especialmente entre los jóvenes, un porcentaje muy significativo de la población brasileña. Entre los factores que contribuyen al aumento de dicho consumo están la permisividad de las leyes y el incumplimiento de las mismas, así como el afán de la industria del alcohol por potenciar su mercado, a través de la publicidad y del desarrollo de nuevos productos. Últimamente, sin embargo, se han producido ciertos cambios en la situación política, tras la creación de una comisión gubernativa destinada a proponer modificaciones en la reglamentación en materia de alcohol y la formación de grupos de base dedicados a concienciar a la sociedad brasileña de los peligros de su consumo.

Palabras clave: alcohol, políticas, industria alcoholera, cumplimiento leyes, Brasil.

\begin{abstract}
This paper presents the current situation of alcohol public policy efforts in Brazil. Epidemiological data shows that alcohol use is on the raise, especially among the youngsters - that represent a significant portion of the Brazilian population. Factors implicated in the increase on consumption include the loose laws in the country, the lack of enforcement, as well as the focus of the alcohol industry in boosting its market, through advertising and development of new products. Recently, however, there seems to be some change on the political climate, with the creation of a government commission to propose alterations on the alcohol regulation and the establishment of a grass-roots group focusing on developing a new awareness about alcohol problems in the country.
\end{abstract}

Key words: alcohol, public policy, law enforcement, Brazil, alcohol industry.

\section{INTRODUCCIÓN}

B rasil continua siendo un país donde el alcohol no es una droga regulada sino prácticamente libre. Hay algunas leyes que establecen la edad legal en que se puede iniciar su consumo (18 años) y que, por ejemplo, prohíben su venta a menores; pero no existe ninguna legislación a nivel nacional que regule el horario de venta del producto o los criterios de concesión de licencias, o que prohíba siquiera su venta en las carreteras. Además de escasear las leyes, rara vez se

\section{INTRODUCTION}

B razil is still a country where alcohol is not, in effect, a regulated drug, but virtually a liberated one. There are some laws stating the legal age of drinking initiation (18 years old) and prohibiting vendors to sell to minors, for instance. However, the country has no national legislation regarding hours to sell the product, stating licensing criteria or even prohibiting alcohol commerce in all roads. In addition to the few regulations, the ones that exist are rarely 
cumplen las existentes. Por ejemplo, en un estudio realizado en Paulinia, en el estado de Sao Paulo, el 98\% de los adolescentes podían comprar bebidas alcohólicas en más de 120 bares de la ciudad. Esta situación queda reflejada en la promoción y publicidad de bebidas alcohólicas que realizan los medios de comunicación. Hace algunos meses, se formó un grupo interministerial destinado a definir la política nacional en materia de alcohol y los problemas relacionados con su consumo, incluyendo aspectos como su publicidad, tratamiento y los impuestos sobre dicho producto. La formación de este grupo, coordinado por el Ministerio de Sanidad, llega en un momento muy significativo, pues los datos epidemiológicos indican que el consumo de alcohol en el país es cada vez más elevado.

\section{DATOS SOBRE EL CONSUMO DE ALCOHOL}

Los estudios epidemiológicos en Brasil evidencian que el consumo de bebidas alcohólicas ha ido en aumento, especialmente entre los jóvenes, durante los últimos quince años. Estos datos vienen respaldados por distintas fuentes, que incluyen dos extensos estudios entre escolares en 1987, 1989, 1993 y 1997 (Galduróz JCF, Noto AR, Carlini EA (1997); encuestas a niños de la calle (Noto AR, Nappo S, Galduróz JCF, Mattei R, Carlini EA (1998); datos de ingresos hospitalarios (Noto AR, Moura YG, Nappo S, Galduroz JCF, Carlini EA 2002); y dos encuestas en hogares brasileños en 1999 y en 2001 (Galduróz JCF, Noto AR, Nappo S, Carlini EA. 2000; Carlini EA, Galduroz JCF, Noto AR, Nappo S 2002). La mayoría de los estudios epidemiológicos han sido efectuados por CEBRID (Centro Brasileño de Información sobre Drogas Psicotrópicas), un centro perteneciente a UNIFESP (Universidad Federal de Sao Paulo).

Los resultados de las encuestas periódicas realizadas en los colegios entre 1987 y 1997 han mostrado que más del $65 \%$ de los estudiantes han consumido alguna vez alcohol, y que el 50\% de los niños entre 10 y 12 años lo ha probado al menos en una ocasión (Galduróz JCF, Noto AR, Carlini EA 1997). Si comparamos los cuatro años en que se llevaron a cabo las encuestas, la frecuencia de consumo de bebidas alcohólicas (seis o más veces al mes) ha sido cada vez mayor en seis de las diez ciudades estudiadas. Por otra parte, el consumo abusivo (veinte o más veces al mes) ha aumentado en ocho ciudades, lo cual es motivo de alarma. (Galduróz JCF, Noto AR, Carlini EA 1997)

Como era de esperar, tanto la frecuencia como la cantidad de drogas consumidas por los niños de la calle son muy elevadas. Los resultados se han mantenido durante los cuatro años (1987/89/93/97) en que se hicieron las encuestas. Entre estos niños, de edades enforced. For instance, in a research in the city of Paulinia, state of São Paulo, more than $98 \%$ of the times teenagers were able to buy alcoholic beverage in more than 120 bars of the city. This situation is reflected in the promotion and advertising of alcoholic advertising in the media. A few months ago, an interministerial group was formed with the objective of defining a national policy against alcohol related problems, including aspects like promotion, treatment and alcohol taxes. The constitution of this group, coordinated by the Minister of Health, comes at an important moment when a number of epidemiological data indicates that the consumption of alcohol by its population has been growing.

\section{DATA ON ALCOHOL USE}

It is clear from Brazil's epidemiological research that the use of alcoholic beverages, particularly among young people, has been increasing over the last 15 years. Research data to support this finding has been drawn from a range of sources, including two large studies conducted among school-aged children in 1987, 1989, 1993 and 1997 (Galduróz JCF, Noto AR, Carlini EA (1997); surveys of street children (Noto AR, Nappo S, Galduróz JCF, Mattei R, Carlini EA (1998); hospital admission data (Noto AR, Moura YG, Nappo S, Galduroz JCF, Carlini EA 2002); and two Brazilian household surveys conducted in 1999 and in 2001 (Galduróz JCF, Noto AR, Nappo S, Carlini EA. 2000; Carlini EA, Galduroz JCF, Noto AR, Nappo S 2002). Most of the epidemiological research in the area of alcohol has been done by CEBRID (Brazilian Center of Information on Psychotropic Drugs), a center located at UNIFESP (Federal University of São Paulo).

Results from school based surveys conducted periodically from 1987 through to 1997 have shown that lifetime use of alcohol is above $65 \%$ for all students, with $50 \%$ of students aged $10-12$ years old having already tried alcohol at least once (Galduróz JCF, Noto AR, Carlini EA (1997). Comparing the four years when the surveys were done, the frequent use of alcoholic beverages (six or more times in a month) has been increasing in six of the ten cities surveyed. In addition, heavy use (defined as use on twenty or more times in a month) grew in eight cities, which is a cause for concern. (Galduróz JCF, Noto AR, Carlini EA (1997).

Not surprisingly, there is a high frequency and quantity of drugs being used by street children. This finding was maintained in the four years (1987/89/93/97) when the surveys were done. Among these children, who ranged in age from 9-18 years, alcohol was not their favorite drug, but its recent use 
comprendidas entre los 9 y los 18 años, la droga preferida no era el alcohol, aunque su consumo reciente (últimos treinta días) oscilaba entre el 30 y el 54\% en las seis ciudades encuestadas, y el consumo diario alcanzaba el 7\% en Sao Paulo (Noto AR, Nappo S, Galduróz JCF, Mattei R, Carlini EA 1998).

Gracias a un acuerdo con el Ministerio de Sanidad Brasileño, CEBRID recibe, desde 1988, información de todos los hospitales del país donde ingresan pacientes con trastornos relacionados con el consumo de drogas. 450 hospitales deberían enviar un informe anual sobre esos pacientes, especificando el sexo, la edad y el diagnóstico. Desgraciadamente, sólo llega una media del $52 \%$ (entre el 35,5 y el $79,6 \%$ ) de esa información. En 1999, último año analizado, se tuvo noticia de 44.680 admisiones, de las que el 84,5\% eran debidas al exceso de alcohol, el 8,3\% a distintas sustancias psicotrópicas, el 4,6\% a la cocaína, y el 1,3\% a la marihuana, entre otros (Noto AR, Moura YG, Nappo S, Galduroz JCF, Carlini EA 2002).

La primera encuesta a los hogares brasileños, realizada en 1999, cubrió las 24 ciudades con más de 200.000 habitantes del estado de Sao Paulo, el más poblado del país, con un total de 2.411 entrevistas. De nuevo el alcohol encabeza la lista de drogas consumidas. Entre los 12 y los 17 años, un 35\% reconocía haber consumido alcohol, y un 2\% tener problemas con dicha sustancia (Galduróz JCF, Noto AR, Nappo S, Carlini EA. 2000). Estas frecuencias son algo inferiores a las de las encuestas escolares, debido quizá a las diferencias metodológicas en la recogida de datos.

La encuesta más reciente y completa realizada en los hogares brasileños, en el año 2001, cubrió las 107 ciudades más grandes del país, lo que representa casi el $40 \%$ de la población brasileña. En ella, un $48 \%$ de los adolescentes entre 12 y 17 años afirmaba haber consumido alcohol, y ese porcentaje era del $73 \%$ entre los 18 y los 25 años. Un 4\% tenía problemas con dicho consumo entre los 12 y los 17 años, y un 10\% entre los 18 y los 25 . Un estudio comparativo de las dos encuestas en los hogares brasileños, concretamente en el estado de Sao Paulo, analizaba juntos los distintos grupos de edad y concluía que el consumo de alcohol había aumentado en los dos últimos años (Galduróz JCF, Noto AR, Nappo S, Carlini EA 2003). El mismo estudio señalaba que dicho aumento podía estar relacionado con una campaña publicitaria de bebidas alcohólicas muy agresiva, especialmente de cerveza.

Recientemente, algunos grupos de investigación brasileños han publicado estudios sobre el consumo de alcohol entre adultos en diferentes zonas del país. Un estudio de Rio Grande do Sul descubrió que un 14,3\% consumía elevadas dosis de alcohol -más de 30g/día- (Costa JS, Silveira MF, Gazalle FK, Oliveira SS, Hallal PC, Menezes AM, et al. 2004) un nivel similar al $13 \%$ encontrado en Bahía (Almeida-Filho N, Lessa I, (last 30 days) was still between $30-54 \%$ in the six cities surveyed and the daily use was as high as $7 \%$ in São Paulo (Noto AR, Nappo S, Galduróz JCF, Mattei R, Carlini EA (1998).

Through an agreement with the Brazilian Health Ministry, CEBRID has been receiving, since 1988, information from hospitals all over the country that admit patients with substance abuse disorders. Every year 450 hospitals are supposed to send information about these patients, including their sex, age and diagnosis. Unfortunately, the mean percentage of information return has been 52\% (range: 35,5-79,6\%). In 1999, the last year analyzed, 44,680 admissions were reported, out of which $84.5 \%$ due to alcohol, $8.3 \%$ due to multiple psychotropic substances, $4.6 \%$ due to cocaine, $1.3 \%$ due to marijuana, among others (Noto AR, Moura YG, Nappo S, Galduroz JCF, Carlini EA 2002).

Brazil's first household survey in 1999 covered the 24 cities with over 200,000 inhabitants in the state of São Paulo, the most populated in Brazil, with a total of 2,411 interviews completed. Once again, alcohol stands at the top of the list of drugs used. Among 12-17 year-olds, lifetime alcohol use was 35\% and 2\% of young people this age admitted to having problems with alcohol (Galduróz JCF, Noto AR, Nappo S, Carlini EA. 2000). These frequencies are somewhat lower than the ones presented in the school surveys and may be due to the methodological differences in data collection.

The most recent and complete household survey, conducted in 2001, covered the 107 largest cities in Brazil, representing almost $40 \%$ of the Brazilian population. Lifetime use of alcohol reported in this survey was $48 \%$ for $12-17$ year-olds and $73 \%$ for $18-25$ year-olds. Problems due to alcohol use were reported by $4 \%$ of the 12 to 17 year-olds and $10 \%$ of the 18 25 year-olds. A paper comparing the two household surveys specifically for the state of São Paulo analyzed all the age groups together and concluded that alcohol lifetime use increased during these two years (Galduróz JCF, Noto AR, Nappo S, Carlini EA (2003). The same paper suggested that this increase may be related to an aggressive alcohol advertising campaign, especially for beer.

Recently, a few research groups in the country published investigations on alcohol use among adults in different parts of the country. A paper from Rio Grande do Sul found a heavy alcohol consumption (above 30g/day) prevalence of 14,3\% (Costa JS, Silveira MF, Gazalle FK, Oliveira SS, Hallal PC, Menezes AM, et al. 2004), similar to the level found in Bahia - 13\% (Almeida-Filho N, Lessa I, Magalhães L, Araújo MJ, Aquino E., Kawachi I, James AS. 2004).

Brazil still lacks, however, a more complete survey that bring information on alcohol patterns for the 
Magalhães L, Araújo MJ, Aquino E., Kawachi I, James AS. 2004)

Sin embargo, sería necesario realizar un estudio más completo que aportara información sobre los hábitos de consumo de alcohol en todo Brasil. El Secretariado Nacional Antidrogas (SENAD) y el Departamento de Psiquiatría de la Universidad Federal de Sao Paulo (UNIFESP) acaban de formalizar un contrato para realizar una encuesta en los hogares, a nivel nacional, exclusivamente sobre el consumo de bebidas alcohólicas a partir de los 14 años. Dicha encuesta terminará a finales de este año y, entre otras cosas, nos proporcionará datos sobre los hábitos de consumo de alcohol, la violencia relacionada con ese consumo y el respaldo a las políticas del alcohol.

\section{LA INDUSTRIA DEL ALCOHOL EN BRASIL: ES- TRUCTURA E IMPORTANCIA}

SINDCERV (Sindicato Nacional de la Industria Cervecera) ha calculado que el consumo medio de alcohol puro en Brasil fue de 5,6 litros per capita en el 2001. La base de datos WHO del año 2000, por otra parte, muestra un consumo medio de 8.6 litros per capita. Teniendo en cuenta que es poco probable que el consumo medio disminuyera tanto en un solo año, es muy posible que la diferencia entre esas dos cifras se deba al hecho de que los datos WHO se refieren al consumo per capita de los adultos (a partir de los 15 años de edad) mientras que los datos SINDCERV se refieren a la totalidad de la población brasileña. El consumo total de cada bebida alcohólica (sin calcular por contenido de alcohol) es de 8,5 billones de litros/año de cerveza, 1,5 billones de litros/año de licores (especialmente cachaza), y 0,3 billones de litros/año de vino.

Una novedad en el mercado de las bebidas alcohólicas son los Ilamados "alcopops". Este producto, una mezcla de licores y bebidas sin alcohol, ha tenido una rápida aceptación entre los jóvenes, y contiene entre un 5 y un 7\% de alcohol. En el mercado brasileño son ejemplos típicos Smirnoff Ice, Bacardi Breezer, Johnny Walker One, and Velho Barreiro Ice. Estas bebidas se han desarrollado para competir con la cerveza y, a pesar del contenido relativamente bajo de alcohol, su publicidad está sujeta a las mismas restricciones que los licores y bebidas de alta graduación.

\section{LA PUBLICIDAD DEL ALCOHOL EN BRASIL}

La industria del alcohol en Brasil gasta anualmente millones de dólares en publicidad para promocionar whole country. Recently, the National Secretary AntiDrugs (SENAD) and the Psychiatry Department of the Federal University of São Paulo (UNIFESP) established a contract to develop a national household survey, exclusively on alcoholic beverages focusing on ages 14 and up. This survey should be concluded by the end of this year and will advance on our knowledge of topics like patterns of alcohol use, violence related to alcohol, alcohol policies support and others.

\section{THE ALCOHOL INDUSTRY IN BRAZIL: STRUCTU- RE AND IMPORTANCE}

SINDCERV (National Syndicate of the Beer Industry), calculates that average per capita consumption of pure alcohol in Brazil was 5.6 litres in 2001. The WHO database for the year 2000, on the other hand, presents an average per capita consumption of 8.6 litres in Brazil. Considering the average consumption probably did not shrink so much in just one year, the difference between these two numbers is probably due to the fact that the WHO data is for adult per capita consumption (people aged 15 or more) and the SINDCERV data takes into account the whole Brazilian population. The total shares of each alcoholic beverage (without calculating by alcohol content) is 8.5 billions of litres/year for beer, 1.5 billions of litres/year for spirits (especially cachaça), and 0.3 billions of litres/year for wine.

A recent development in the alcohol beverage market in Brazil is the introduction of so-called "alcopops". These products have had relatively quick acceptance by the young population, and have an alcoholic content of about $5-7 \%$ in a mixture of spirits and soft drinks. Typical examples on the Brazilian market are Smirnoff Ice, Bacardi Breezer, Johnny Walker One, and Velho Barreiro Ice. These drinks have been developed to compete with beer for some of their market share, and despite their relatively low alcohol content, the advertising of these products are subject to the same media restrictions as those of spirits.

\section{ALCOHOL ADVERTISING IN BRAZIL}

The alcohol industry in Brazil spends, annually, millions of dollars on media advertising promoting its products. The only scientific study published to date on the practices of Brazilian alcohol advertising collected data between 1992-1994 and found that the frequency of alcohol advertising in television was 
sus productos. El único estudio científico publicado hasta la fecha sobre las prácticas de publicidad del alcohol recogió datos entre 1991 y 1994, y puso de manifiesto que la publicidad del alcohol en televisión era mayor que la publicidad de otros productos como el tabaco y las bebidas no alcohólicas (Pinsky, Araujo, 1999). Este estudio mostraba que la relajación, las llamadas al nacionalismo y la conformidad a las reglas del grupo estaban entre los temas más frecuentes higher than the frequency of other products such as cigarettes and nonalcoholic beverages (Pinsky I, Silva MTA. 1999). This study showed that relaxation, appeals to nationalism, and conformity to group rules were among the most frequent themes.

Tabla 1. Cantidad gastada en anuncios de alcohol en los medios (1997-2001)* Table 1. Amount spent on Alcohol Ads in the Media (1997-2001)*

\begin{tabular}{|c|c|c|c|c|c|}
\hline $\begin{array}{l}\text { Bebidas alcohólicas (sin cerveza) } \\
\text { Alcoholic Beverages (excluding beer) }\end{array}$ & 1997 & 1998 & 1999 & 2000 & 2001 \\
\hline $\begin{array}{l}\text { Inversión publicitaria - } \mathrm{R} \$^{* *} \\
\text { Publicity investment- } R \$^{* *}\end{array}$ & 39,620 & 45,940 & 52,038 & 55,632 & 64,571 \\
\hline $\begin{array}{l}\text { Variación \% en comparación con el año anterior } \\
\text { Variation \% compared to past year }\end{array}$ & $7.1 \%$ & $16.0 \%$ & $13.3 \%$ & $6.9 \%$ & $16.1 \%$ \\
\hline $\begin{array}{l}\text { Inversión publicitaria - US\$** } \\
\text { Publicity investment - US\$ }\end{array}$ & 36,363 & 39,038 & 25,525 & 26,179 & 21,217 \\
\hline Importancia de cada medio/Importance of each media & a $\%$ & $\%$ & $\%$ & $\%$ & $\%$ \\
\hline Periódico / Newspaper & $3.8 \%$ & $4.0 \%$ & $3.8 \%$ & $2.4 \%$ & $2.9 \%$ \\
\hline Exteriores / Outdoor & $0.0 \%$ & $2.9 \%$ & $3.4 \%$ & $3.0 \%$ & $3.9 \%$ \\
\hline Revista / Magazine & $20.9 \%$ & $18.2 \%$ & $21.8 \%$ & $23.6 \%$ & $23.0 \%$ \\
\hline Radio / Radio & $0.0 \%$ & $0.0 \%$ & $3.9 \%$ & $5.3 \%$ & $6.7 \%$ \\
\hline TV / TV & $75.3 \%$ & $75.0 \%$ & $61.9 \%$ & $57.8 \%$ & $47.2 \%$ \\
\hline TV Cable / Cable TV & $0.0 \%$ & $0.0 \%$ & $5.2 \%$ & $7.9 \%$ & $16.3 \%$ \\
\hline Cerveza / Beers & 1997 & 1998 & 1999 & 2000 & 2001 \\
\hline $\begin{array}{l}\text { Inversión publicitaria - } \mathrm{R} \$^{* *} \\
\text { Publicity investment }-R \$^{* *}\end{array}$ & 138,153 & 144,167 & 143,314 & 169,016 & 198,287 \\
\hline $\begin{array}{l}\text { Variación \% en comparación con el año anterior } \\
\text { Variation \% compared to past year }\end{array}$ & $19.5 \%$ & $4.4 \%$ & $-0.6 \%$ & $17.9 \%$ & $17.3 \%$ \\
\hline $\begin{array}{l}\text { Inversión publicitaria - US\$\$* } \\
\text { Pubocity investment - US\$ } \$^{* *}\end{array}$ & 127,794 & 124,671 & 77,081 & 92,412 & 85,811 \\
\hline Importancia de cada medio/Importance of each media & a $\%$ & $\%$ & $\%$ & $\%$ & $\%$ \\
\hline Periódico / Newspaper & $5.0 \%$ & $4.0 \%$ & $5.1 \%$ & $3.0 \%$ & $3.5 \%$ \\
\hline Exteriores / Outdoor & $0.0 \%$ & $0.0 \%$ & $0.7 \%$ & $0.2 \%$ & $1.0 \%$ \\
\hline Revista / Magazine & $2.0 \%$ & $4.0 \%$ & $5.5 \%$ & $1.3 \%$ & $3.5 \%$ \\
\hline Radio / Radio & $7.0 \%$ & $0.0 \%$ & $0.0 \%$ & $0.0 \%$ & $0.0 \%$ \\
\hline TV / TV & $86.0 \%$ & $92.0 \%$ & $88.7 \%$ & $95.5 \%$ & $92.1 \%$ \\
\hline TV Cable / Cable TV & $0.0 \%$ & $0.0 \%$ & $0.0 \%$ & $0.0 \%$ & $0.0 \%$ \\
\hline \multicolumn{6}{|c|}{$\begin{array}{l}\text { * La cerveza se presenta por separado a fin de mostrar explícitamente la diferencia de las inversiones / Beer is presented separately in order to show explicitly the } \\
\text { difference in investments. } \\
{ }^{* *} \text { Reales brasileños. } \\
\text { Fuente: IBOPE/Monitor (Tendências, 2001) / Source: IBOPE/Monitor (Tendências, 2001). }\end{array}$} \\
\hline
\end{tabular}

La tabla 1 muestra que en el año 2001 se gastaron más de 106 millones de dólares USA en publicidad de bebidas alcohólicas; el $80 \%$ de esa cantidad fue destinada a anuncios de cerveza. Dicha cantidad se redujo entre 1998 y 2001, pero en reales (moneda brasileña)
Table 1 shows that a total of more than USD $\$ 106$ million was spent in alcohol advertising in the year $2001 ; 80 \%$ of this amount was due to beer ads. The amount spent in dollars was reduced from 1998 to 2001, but in Reais (Brazilian currency), the investment 
la inversión aumentó (más que la inflación nacional especialmente en el caso de la cerveza). La mayoría de los anuncios de cerveza se difundieron por televisión, mientras que las demás bebidas alcohólicas se promocionaron sobre todo en revistas. La segunda bebida alcohólica que más gastó en publicidad fue la cachaza.

Para situar esas inversiones en su justo contexto hay que compararlas con las realizadas para promocionar alimentos salados, alimentos dulces y bebidas $\sin$ alcohol. Estos productos gastaron respectivamente en publicidad 24,7 millones de dólares USA, 71 millones de dólares USA y 68,2 millones de dólares USA. El total gastado en anuncios de cerveza sobrepasa ampliamente estas cifras.

La principal ley federal que regula la publicidad del alcohol fue aprobada en 1996 y controla, asimismo, la publicidad de medicamentos, pesticidas y tabaco. Su objetivo prioritario es restringir el horario de difusión en radio y televisión. Bajo esta ley, la publicidad del alcohol (bebidas alcohólicas son aquellas que contienen más de $13 \mathrm{GL}$ de alcohol) sólo se permite de 9 pm a 6 am. Esta restricción, sin embargo, se aplica solamente a las bebidas alcohólicas con más de $13 \mathrm{GL}$, lo que significa que la cerveza puede anunciarse a cualquier hora. Por otra parte, lo que conocemos como "llamadas", anuncios de menos de cinco segundos de duración en los que presenta una marca, no tienen la menor restricción horaria. Además de limitar las horas de difusión, la ley incluye ciertas restricciones sobre el contenido de los anuncios de bebidas alcohólicas. Entre éstas, la ley establece que la publicidad no debe asociar el consumo de alcohol con la práctica de deportes o con las situaciones peligrosas o ilegales.

Unos años después se propuso una nueva ley que reemplazara la de 1996. Esta nueva ley, mucho más dura y aprobada en diciembre del año 2000, sirvió para prohibir la publicidad del tabaco en los medios, limitando básicamente su promoción a los puntos de venta Aunque la nueva normativa no prohibió la publicidad del alcohol en los medios, el clima político cambio. Como resultado, se propusieron varias leyes para aumentar las restricciones o prohibir la publicidad de las bebidas alcohólicas. En enero de 2002 se presentaron más de 50 propuestas ante el Congreso Brasileño, sugiriendo limitaciones que iban desde la exigencia de etiquetas que advirtieran de los peligros del consumo hasta la total prohibición de los anuncios de bebidas alcohólicas en los medios, incluyendo el vino y la cerveza. La industria publicitaria, tratando de anticipar y evitar nuevas normativas que le llegaran del exterior, aprobó en el año 2003 una serie de revisiones a su código de autorregulación (restringir el uso de contenidos sexuales y de dibujos, sólo contratar modelos mayores de 25 años, etc...). En esta nueva versión de su código, las bebidas alcohólicas están separadas en tres categorías: más de 13 ABV, cerveza y vino, y alcopops. increased (more than the national inflation, especially in the case of the beer). Most of the beer advertising was done on television, while for the other alcoholic beverages, magazine advertising was widely used. The second alcoholic beverage responsible for much of the media investment was "cachaça".

These investments can be put into context when compared with media investment for salty and sweet food and for non-alcoholic beverages. Respectively, these products spent USD\$24.7 million, USD\$ 71 million and USD\$68.2 million in media advertising in 2001 - the amount spent by the beer ads easily outstrips these numbers.

The main federal law regulating alcohol advertising was enacted in 1996 and also controls the advertising of medicines, agriculture poison products and tobacco products. Its main intent is the restriction of times for broadcast on television and radio. Under this law, alcohol advertising (alcoholic beverages here are the ones with alcohol content superior to $13 \mathrm{GL}$ ) is only permitted between 9pm and 6am. This restriction however, only applies to alcoholic beverages with alcohol content over $13 \mathrm{GL}$ - which means that beer is unrestricted. In addition, the so-called "chamadas", ads lasting five or less seconds where a brand name is depicted, is permitted at any time. As well as the time restrictions, the law also includes some restrictions on the content of the alcohol advertisements. Among the content restrictions, the law establishes that the alcohol advertisements should not associate alcohol consumption to the practice of sports or dangerous or illegal situations.

A new law was proposed a few years later to replace the 1996 one. This tough law, approved in December 2000, served to ban tobacco advertising in the media, basically restricting promotions to point-of-sale advertising associated with tobacco products. Although the new regulation did not include alcohol advertisements in the media ban, the political climate changed. As a consequence, a number of laws were proposed to further restrict or ban alcohol beverages advertisements. By January 2002 more than 50 proposals were before the Brazilian Congress, suggesting restrictions ranging from requiring warning labels through to the total ban of alcohol beverage ads in the media, including those of beer and wine. The advertising industry, trying to anticipate and avoid further outside regulation, in September 2003 approved revisions to its self-regulation code (restriction in the use of sexual content and cartoons, models featured in the advertisements should be and appear to be older than twenty-five, etc.). In this new version of the code, alcoholic beverages are actually separated into three categories: those above $13 \mathrm{ABV}$, alcohol and wine, and alcopops. 


\section{SITUACIÓN ACTUAL}

Las propuestas del primer grupo interministerial han concluido este año y están siendo estudiadas en la actualidad. A pesar de que fueron discutidas durante casi un año, hubo aspectos en los que el grupo no llegó a ningún acuerdo. Por ejemplo, las propuestas para aumentar los impuestos sobre el alcohol (y, en consecuencia, los precios del alcohol) y para acabar con los incentivos para la producción de alcohol (relacionados con la producción de cachaza, la bebida nacional, con un porcentaje muy elevado de alcohol), fueron criticados tanto por el sector gubernativo como por la industria del alcohol. Argumentaron que podrían ocasionar graves pérdidas económicas para el país. Es evidente que la verdadera disputa está entre las prioridades económicas a corto plazo y las pérdidas de salud pública y a largo plazo. Sin el respaldo de unos estudios del coste nacional que muestren las cifras implicadas en toda clase de problemas relacionados con el alcohol, los datos más visibles son los defendidos por la industria del alcohol (puestos de trabajo, financiación de algunas campañas políticas, etc...). Algunos sectores de la industria del alcohol, especialmente representantes de los productores de cerveza, lanzaron campañas destinadas a mejorar su "reputación" y evitar ser incluidos en las restricciones publicitarias. Por ejemplo, la compañía cervecera más importante de Brasil, AMBEV, inició una buena campaña publicitaria para prevenir la conducción de vehículos en estado de embriaguez, incluyendo la donación de varios alcoholímetros a la policía militar, la asociación con representantes de los taxistas y la puesta en marcha de una iniciativa destinada a reducir el consumo de alcohol entre menores de edad. La industria ha presionado también a los políticos y ha invitado (con éxito) a los profesionales de la sanidad pública a aunar esfuerzos.

Otra novedad muy interesante ha sido la constitución de un grupo de defensa independiente. Este grupo, Ilamado "Alianza Ciudadana para el Control del Alcohol", fue formado inicialmente por profesionales de la sanidad pública, pero ha ido consiguiendo el apoyo de distintos segmentos de la sociedad (organismos de control, grupos religiosos, colegios, asociaciones de amas de casa, club de Rotarios, etc...). El grupo se mueve básicamente en dos direcciones. Por un lado, reunir datos de distintos estudios e investigaciones para demostrar que las políticas estatales son más eficaces a la hora de reducir los daños relacionados con el alcohol. Por otro, y éste es su principal objetivo político, conseguir apoyo (a través de una petición que busca recoger más de un millón de firmas) para que la ley prohíba o establezca severas limitaciones a la publicidad del alcohol, igualando su situación a la del tabaco. Como es natural, este grupo está encontrando una fuerte resistencia, incluso entre algunos trabajadores sanitarios; pero también ha conseguido respaldo en los lugares más insospechados.

\section{CURRENT SITUATION}

The first interministerial group proposals have been concluded this year and sent to further appreciation.. Despite the fact the proposals were discussed for almost a year, the group was not able to reach consensus in a number of aspects. For instance, the propositions on increasing alcohol taxes (and, consequently, alcohol prices) and the end of incentives for alcohol production (related to the production of "cachaça", a national beverage, with a very high alcohol percentage), were criticized by both sectors of the government and the alcohol industry. It was claimed that they could bring economical losses for the country. The real dispute it is, of course, related to short-term economical priorities versus long-term losses and public health ones. Without the support of national cost studies showing the numbers implicated in all sorts of alcohol related problems, the more visible data is the one lobbied by the alcohol industry, related to jobs, alcohol sellings and finance to some politicians' campaigns.

Some sections of the alcohol industry, especially those representing the beer producers, launched campaigns intended to improve its "reputation" and avoid being included in the advertising restrictions. For instance, the biggest brewer in Brazil, AMBEV, initiated a well publicized drunk driving prevention campaign, including the donation of several breathalyzers to the military police and a partnership with cabs' representatives and a related initiative to curtail alcohol consumption among minors. The industry has also been lobbying, pressuring politicians and inviting (with some success) public health professionals to join efforts.

A very interesting and new development was the constitution of an independent advocacy group. This group, named "Aliança Cidadã pelo Controle do Álcool" was initially formed by public health professionals, but has been gaining support from a diverse array of segments of the society (watchdog groups, religious groups, schools, housewives societies, Rotary club, etc.). The group is moving in two main directions. For one side, this group developed a document putting together researchbased knowledge on which public policies are more efficient to reduce alcohol-related harm. Politically, the group is focusing primarily in gaining support (through a petition aiming to collect 1 million signatures) for legislation to prohibit or severely restrict alcohol advertising, in a similar way to the situation of tobacco promotion in the country. Evidently this movement is encountering resistance, even among some health workers, but support from unexpected places has also been found. 


\section{REFERENCIAS}

Almeida-Filho N, Lessa I, Magalhães L, Araújo MJ, Aquino E., Kawachi I, James AS. (2004) Alcohol drinking patterns by gender, ethnicity, and social class in Bahia, Brazil. Revista de Saúde Pública, 38: 45-54.

Carlini EA, Galduroz JCF, Noto AR, Nappo S (2002) I Levantamento Domiciliar sobre o Uso de Drogas Psicotrópicas no Brasil - 2001. São Paulo, CEBRID.

Costa JS, Silveira MF, Gazalle FK, Oliveira SS, Hallal PC, Menezes AM, Gigante, DP, Olinto MT, Macedo S. (2004) Heavy alcohol consumption and associated factors: a population-based study. Revista de Saúde Pública, 38: 284-91.

Galduróz JCF, Noto AR, Carlini EA (1997) IV Levantamento sobre o Uso de Drogas entre Estudantes de $1^{\circ}$. e $2^{\circ}$. graus em 10 Capitais Brasileiras - 1997. São Paulo, CEBRID.

Galduróz JCF, Noto AR, Nappo S, Carlini EA. (2000). I Levantamento Domiciliar Nacional sobre o Uso de Drogas Psicotrópicas - Parte A: estudo envolvendo as
24 maiores cidades do estado de São Paulo.São Paulo, CEBRID.

Galduróz JCF, Noto AR, Nappo S, Carlini EA (2003) Comparações dos resultados de dois levantamentos domiciliares sobre o uso de drogas psicotrópicas no estado de São Paulo nos anos de 1999 e 2001. Jornal Brasileiro de Psiquiatria, 52: 43-51.

Noto AR, Nappo S, Galduróz JCF, Mattei R, Carlini EA (1998) IV Levantamento sobre o Uso de Drogas entre Crianças e Adolescentes em Situação de Rua de Seis Capitais Brasileiras - 1997. São Paulo, CEBRID.

Noto AR, Moura YG, Nappo S, Galduroz JCF, Carlini EA (2002). Internações por transtornos mentais e de comportamentos decorrentes de substâncias psicoativas: um estudo epidemiológico nacional do período de 1988 a 1999. Jornal Brasileiro de Psiquiatria, 51: 113-121.

Pinsky I, Silva MTA. (1999). A frequency and content analysis of alcohol advertising on Brazilian television. Journal of Alcohol Studies, 60, 394-399.

Tendências (2001) São Paulo, A.C. Nielsen. 